\title{
Analysis reveals potential rangeland impacts if Williamson Act eliminated
}

by William C. Wetzel, lara L. Lacher, Daniel S. Swezey, Sarah E. Moffitt and Dale T. Manning

\section{California budget cuts have resulted in dramatic reductions in state funding for the Williamson Act, a land protection} program that reduces property taxes for the owners of 15 million acres of California farms and rangeland. With state reimbursements to counties eliminated, the decision to continue Williamson Act contracts lies with individual counties. We investigated the consequences of eliminating the Williamson Act, using a geospatial analysis and a mail questionnaire asking ranchers for plans under a hypothetical elimination scenario. The geospatial analysis revealed that $72 \%$ of rangeland parcels enrolled in Williamson Act contracts contained habitat important for statewide conservation goals. Presented with the elimination scenario, survey respondents reported an intention to sell $20 \%$ of their total 496,889 acres. The tendency of survey participants to respond that they would sell land was highest among full-time ranchers with low household incomes and without off-ranch employment. A majority (76\%) of the ranchers who reported that they would sell land predicted that the buyers would develop it for nonagricultural uses, suggesting substantial changes to California's landscape in a future without the Williamson Act.

$\mathrm{R}$ anching provides broad social, economic and environmental benefits to the state of California (Huntsinger and Hopkinson 1996; Knight et al. 1994, 2002). Properly managed rangeland can conserve important ecosystem services, including the delivery of fresh water and maintenance of habitats vital for native flora and fauna (Barry and Huntsinger

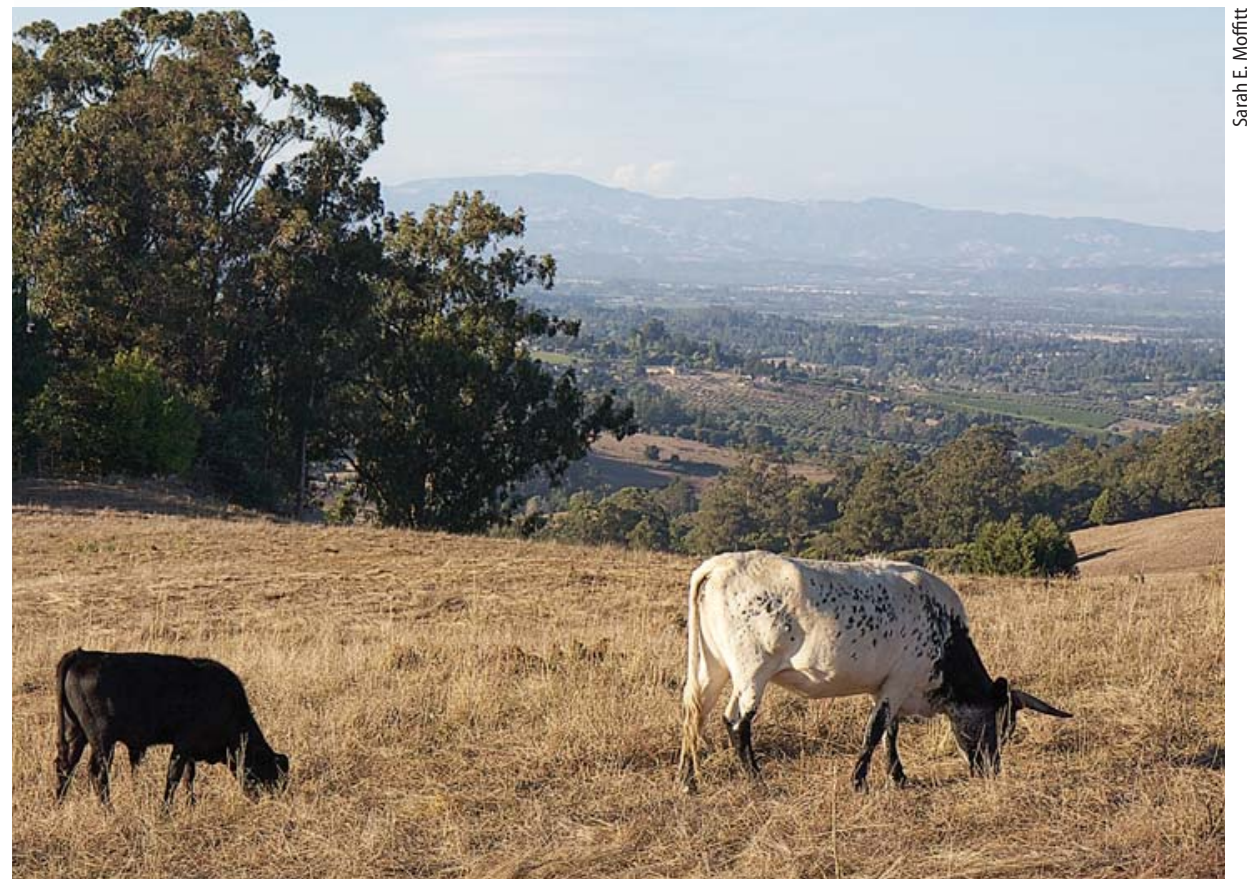

The Williamson Act reduces property taxes for private owners of California farmland and rangeland. In a survey, ranchers were asked what their plans would be for their land if the tax benefit were eliminated. Above, cattle graze near Santa Rosa.

2002; Marty 2004). California ranching has faced an increasingly volatile economic climate in recent years (Andersen et al. 2002). The rate of rangeland development in California for nonagricultural uses exceeds the landscape conversion rate for both forest and croplands, and this accelerating development is predicted to continue for rangelands surrounding California's Central Valley (CDF-FRAP 2010). This development pressure threatens both the ranching industry and the native species that depend on rangeland for survival.

The economic success of ranching in California is intertwined with the California Land Conservation Act of 1965 (known as the Williamson Act), one of the nation's oldest agricultural conservation programs. The goal of the Williamson Act is to preserve agricultural and open space lands by encouraging landowners to stay in agricultural production through reduced property tax rates. Under the Williamson Act, landowners voluntarily commit to maintaining their land in agricultural production under a local county contract for a minimum of 10 years. In return, landowners receive a reduction in their annual property taxes. Under the original program, contract-holding counties received annual subvention payments from the state in proportion to their enrollment and to the productivity of the enrolled lands. These funds helped compensate for the tax revenue losses counties faced due to their participation in the program. Since 1965, thousands of California ranchers and 53 of the 58 counties in California have enrolled in the Williamson Act program.

Beginning in budget year 2008-2009, California drastically reduced subvention reimbursements to counties as part of a plan to phase out the program. In 2009-2010, California Governor Arnold Schwarzenegger cut state subvention funding to $\$ 1,000$, essentially eliminating state support. In 2008, before subvention payments were cut, state reimbursements to counties ranged from $\$ 5.2$ million in

Online: http://californiaagriculture.ucanr.edu/ landingpage.cfm?article=ca.v066n04p131\&fulltext=yes DOI: 10.3733/ca.v066n04p131 
heavily agricultural counties (e.g., Fresno, Kern, Tulare) to less than $\$ 12,000$ in more urbanized counties (e.g., Orange, San Bernardino). In 2010, in response to subvention payment loss, Imperial County ended its participation in the program, nonrenewing (allowing contracts to expire) contracts countywide. Under mount- allocated exclusively to counties; for many counties this is projected to compensate for lost state subvention payments. If landowners agree to enter into the shorter contracts, counties would presumably be encouraged to stay in the program because they avoid losing property tax revenue. Because the state has not approved

\section{Williamson Act savings may make a critical difference in turning a profit versus taking a loss for the majority of California ranchers.}

ing budget deficits, a number of counties placed a moratorium on new contracts because of uncertainty surrounding the future of subvention payments (Sokolow 2010).

Assembly Bill 1265 (passed in 2011) offers counties the option to continue Williamson Act contracts while giving them an opportunity to recoup some lost tax revenues. Under AB 1265, a county can shorten Williamson Act contracts by $10 \%$ and increase the assessed value of land by $10 \%$ of the difference between Proposition 13 values and the Williamson Act assessed value. This option becomes available if state subvention payments fall below half of a county's actual foregone general fund property tax revenue. This increased property tax revenue is funding for future subvention payments, the decision to continue the program under this new structure has fallen into the hands of individual counties.

Using a mail survey and landscape analysis, we explored the economic and ecological impacts if counties decided to eliminate Williamson Act contracts.

\section{Survey design and delivery}

In 2010, we collaborated with the California Cattlemen's Association (CCA), a ranching membership association, to randomly survey 702 CCA members from 33 counties of California's Central Valley and surrounding foothills. We used stratified random sampling to select $62 \%$ of the region's CCA members. We chose these counties because they overlapped with

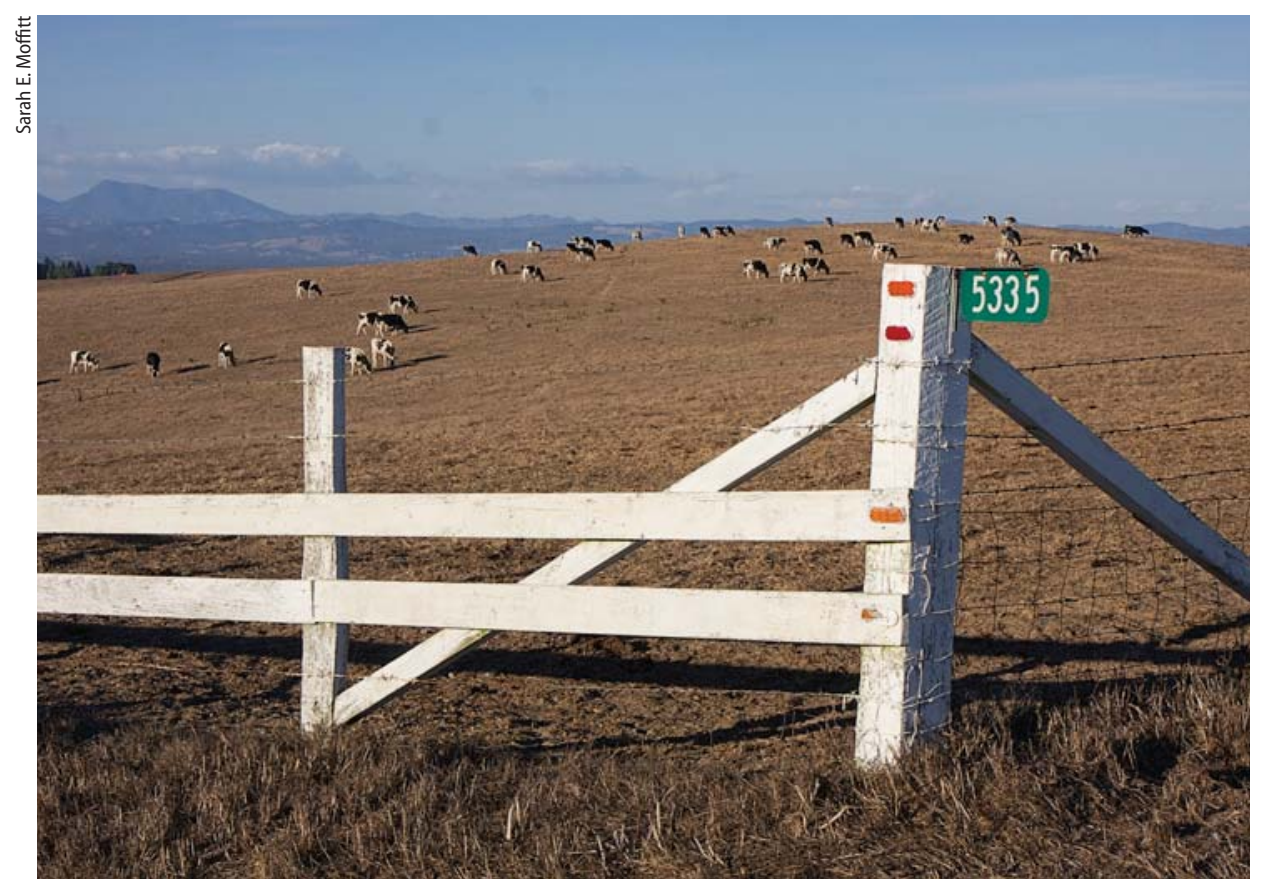

Under a hypothetical elimination scenario for Williamson Act contracts, ranchers predicted that about three-quarters of the land sold in response would be commercially developed. Conversely, $80 \%$ said that their heirs would continue grazing the land if the contracts continued.

a California Rangeland Conservation Coalition study of sensitive rangeland habitats (CRCC 2007b). In a few cases, respondents owned additional land in counties not included in the CRCC study. We used the Dillman (2000) method for mail questionnaires to ask ranchers about their Williamson Act contracts, ranching operation finances, attitudes toward the Williamson Act and future ranching plans. The questions forming the core of our analysis asked ranchers for their plans in the hypothetical event that their Williamson Act-sponsored tax reductions were eliminated. Additional demographic, fiscal and geographic information was also collected.

Survey responses to hypothetical scenarios are typically subject to biases (List and Gallet 2001). In our survey, respondents had a potential financial interest in maintaining Williamson Act funding and thus may have perceived an incentive to report exaggerated consequences of contract elimination. We deal with this potential bias by interpreting results as relative vulnerabilities instead of as exact predictions of future behavior and land use. Comparisons of relative vulnerabilities are justified because ranchers in all socioeconomic categories benefit from their Williamson Act contracts and all may have perceived an incentive to respond in ways that protect the Williamson Act. Where we discuss absolute sizes of reported impacts, we interpret them as upper limits for rancher responses to the loss of Williamson Act contracts.

We received responses from $52 \%$ of the 702 ranching businesses randomly selected for our survey. Of the 364 returned surveys, 294 (84\%) reported ownership of rangeland in California and 57 (16\%) responded that they exclusively leased land for their livestock operations. Of the landowners, 244 (83\%) indicated that they held Williamson Act contracts. Not all 244 respondents answered every question, so sample sizes varied by question.

We used an exploratory data analysis approach to summarize relationships in the survey responses. Our approach involved graphing response and independent variables followed by a visual assessment of any relationships conforming to particular hypotheses. The strength of this approach is that it is robust to nonlinearity and outliers because it makes few 
assumptions about shapes of curves and distributions of data (Bolker 2008).

\section{Landscape analysis}

We used ArcGIS software to calculate the percentage of nonprime Williamson Act contract parcels in the 33 counties that overlapped with sensitive habitat on the CRCC's biological prioritization map (CRCC 2007b), which identifies areas of privately owned rangeland that "have high biodiversity value and require conservation action in the next 2 to 10 years" (CRCC 2007a). We chose nonprime parcels because they are primarily rangeland. The Williamson Act defines prime and nonprime land based on per-acre production value.

We based the analysis on the percentage of parcel overlap instead of area of overlap because a large portion of publicly available county data contained insufficient acreage data. We obtained the Williamson Act parcel data from county websites. San Benito and San Joaquin counties did not have prime/ nonprime designations in their publicly available Williamson Act parcel data. For these two counties, we used data on the distribution of grazing land from California's Farmland Monitoring and Mapping Program (FMMP) to deduce the Williamson Act categories of unlabeled Williamson Act parcels. This was done by extracting parcels within the county that were also designated as grazing land by the FMMP. Therefore, for these counties we assume grazing Williamson Act land is also nonprime Williamson Act land.

\section{Importance of property tax reductions}

Opinions and perceptions. The majority of ranchers (91\% of 237) reported that the Williamson Act was "very important" or "extremely important" for the "long-term viability of their cattle and rangeland operations" and for "ranching in California as a whole" (96\% of 240$)$; the rest said it was "slightly," "somewhat," or "not at all" important for their ranch and ranching in California as a whole. Enrolled ranchers estimated a $\$ 10,000$ median annual property tax reduction through their participation in Williamson Act contracts (with a range from $\$ 1,000$ to $\$ 120,000$ ), which fits with county estimates of rancher savings over their Proposition 13 property taxes (e.g., in 2003 Yolo County estimated a per-acre savings of $\$ 6$ to $\$ 15$; Sokolow and Bennett 2004).

The proportion of ranchers who reported that the Williamson Act was important for the long-term viability of their rangeland operations decreased with increasing household income level. Those who identified as part-time ranchers, or as ranchers who were additionally employed off-ranch, also placed reduced overall importance on the Williamson Act. Opinions regarding the importance of the Williamson Act did not vary by ranch acreage, years spent ranching, estimated land values, estimated ranch profit, rancher age or previous land sale history. The result that Williamson Act importance varies with household income but not with ranch profit is also true for vulnerability to selling.

Profits and savings. Seventy-three percent of respondents reported that in 2009

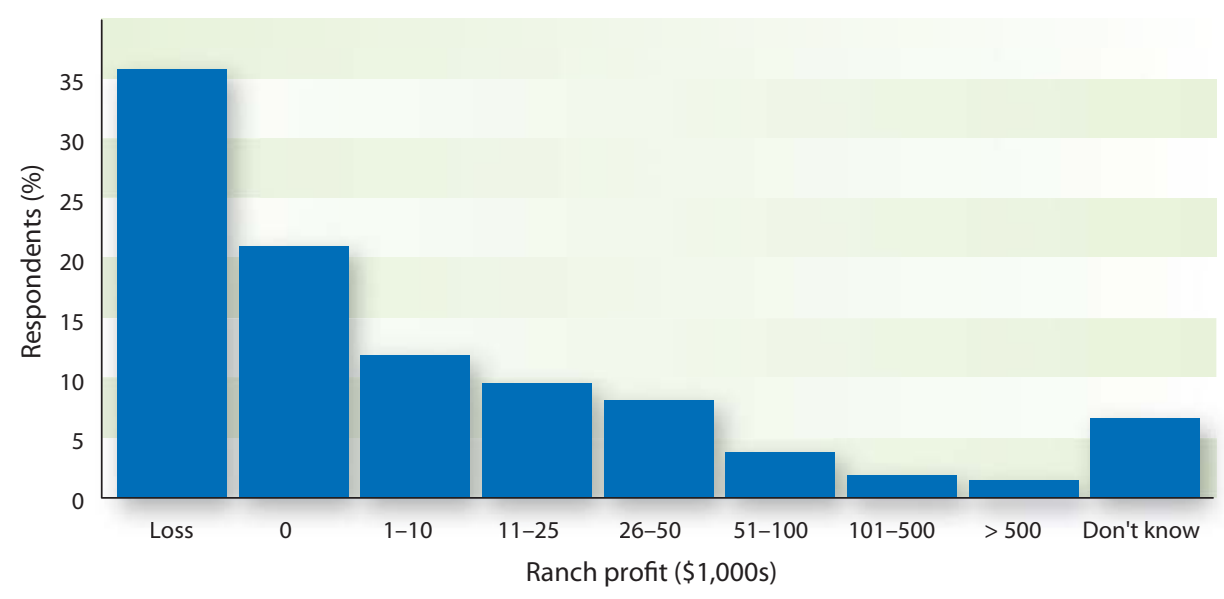

Fig. 1. Ranching operation profits reported by survey respondents who had land enrolled in Williamson Act program, $2009(n=196)$.

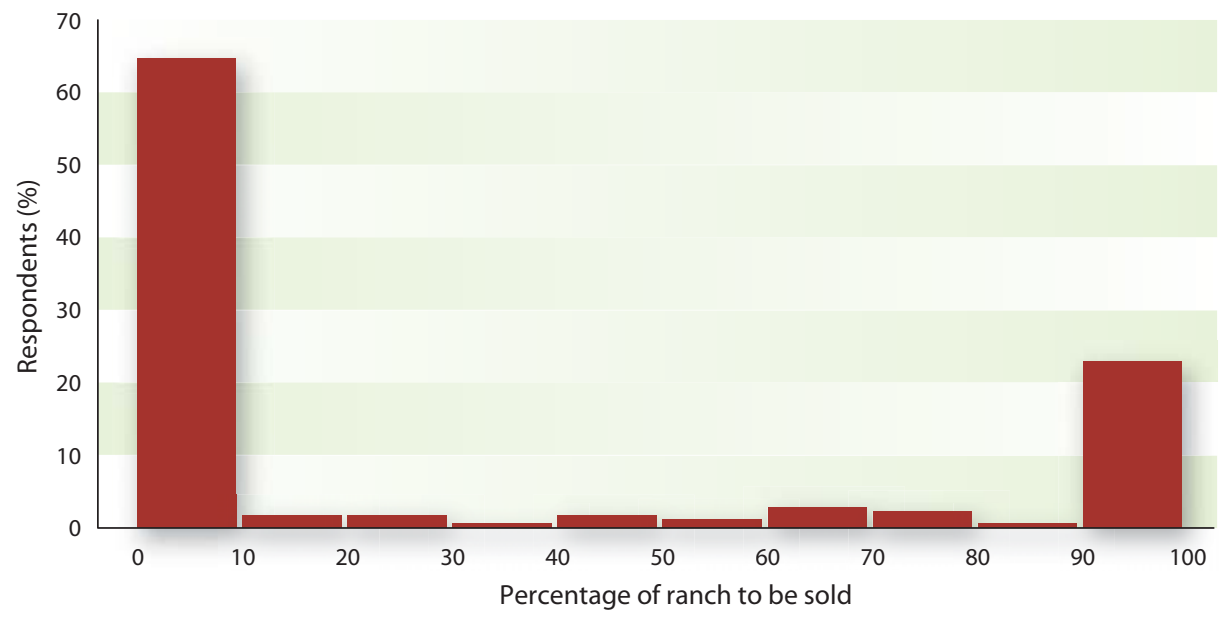

Fig. 2. Rancher estimates of percentage of rangeland they would attempt to sell given elimination of Williamson Act contracts $(n=175)$. Answers are binned into $10 \%$ increments. they earned less than $\$ 10,000$ in annual profit from their ranching businesses (fig. 1) and 71\% reported that their annual profit was equal to or less than their Williamson Act savings. Ninety-three percent of ranchers earning less than $\$ 10,000$ in annual profit reported that their Williamson Act savings exceeded their profit in 2009. These results indicate that Williamson Act savings may make a critical difference in turning a profit versus taking a loss for the majority of California ranchers.

\section{Propensity to sell land}

On average, ranchers said they would sell $29 \% \pm 3.2 \%$ (mean \pm standard error) of their owned rangeland under the hypothetical scenario of Williamson Act contract elimination. Ranchers tended to plan to sell all or none of their ranch with relatively few planning to sell parts of 
ranches (fig. 2). Only $18 \%$ of respondents reported that they would sell a portion of their ranch, whereas $19 \%$ planned to sell all and $63 \%$ planned to sell none. Respondents intended to sell a total of 99,137 acres, or $20 \%$ of the total owned acreage reported.

These numbers give an indication of rancher-stated intentions, not the true amount of land that would be sold. We interpret them as upper bounds on the true values for two reasons. First, not all intentions to sell land translate into land sales; it can often be difficult to find buyers. Second, this is a hypothetical scenario and responses on reported intent to sell could be exaggerated.

\section{Williamson Act parcel vulnerability}

We used two metrics to assess a ranch's vulnerability in the Williamson
Act contract elimination scenario: the estimated probability of selling a ranch (on a scale from 1 to 5), and the estimated percentage of ranch acreage respondents would intend to sell. The choice of metric did not change the conclusions of the analysis, so we present results only for the estimated percentage of ranch acreage intended to be sold. The vulnerability metrics varied most strongly with household income, off-ranch employment and additional operational income from ranch sources other than livestock production (e.g., tourism, hunting, firewood operations). There was no clear relationship between vulnerability and other rancher or ranch enterprise characteristics (analysis not shown), including years spent ranching, estimated land sale price, ranch distance from town and history of nearby development, among many others. Our

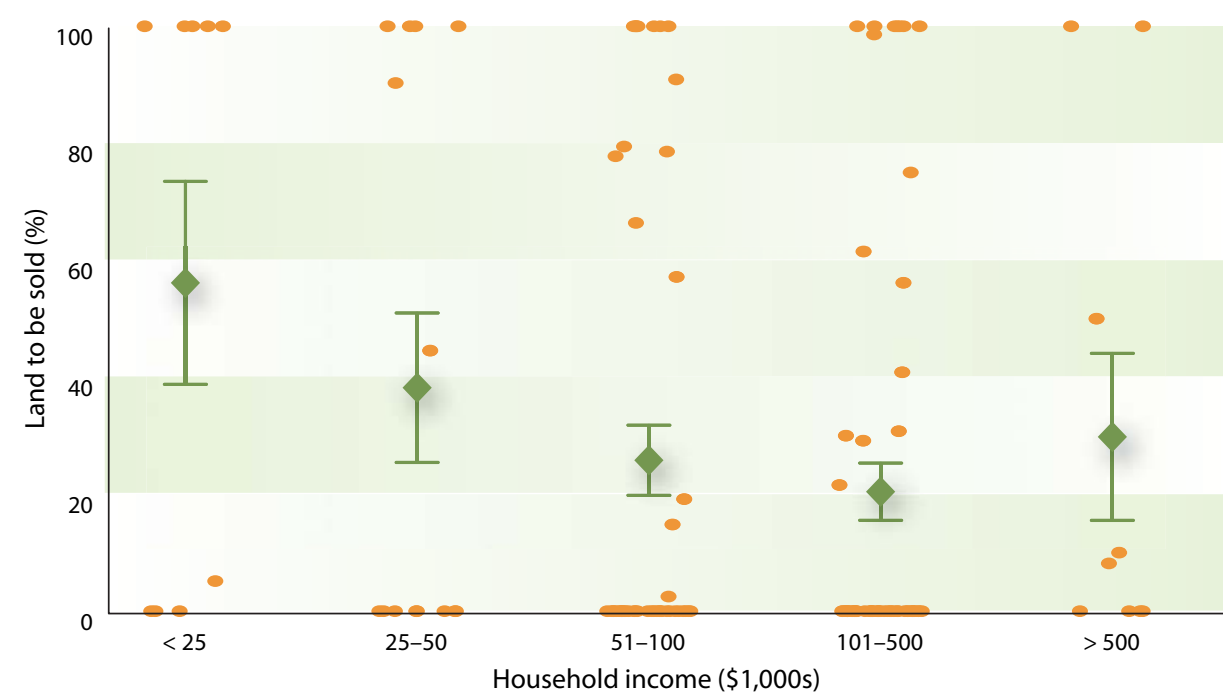

Fig. 3. Percentage of owned ranchland that respondents in different household income categories reported they would attempt to sell given elimination of the Williamson Act $(n=134)$. Green diamonds are the average percentage of ranchland to be sold; green lines show one standard error above and below the mean; orange points show actual data points spread out horizontally within each household income category.

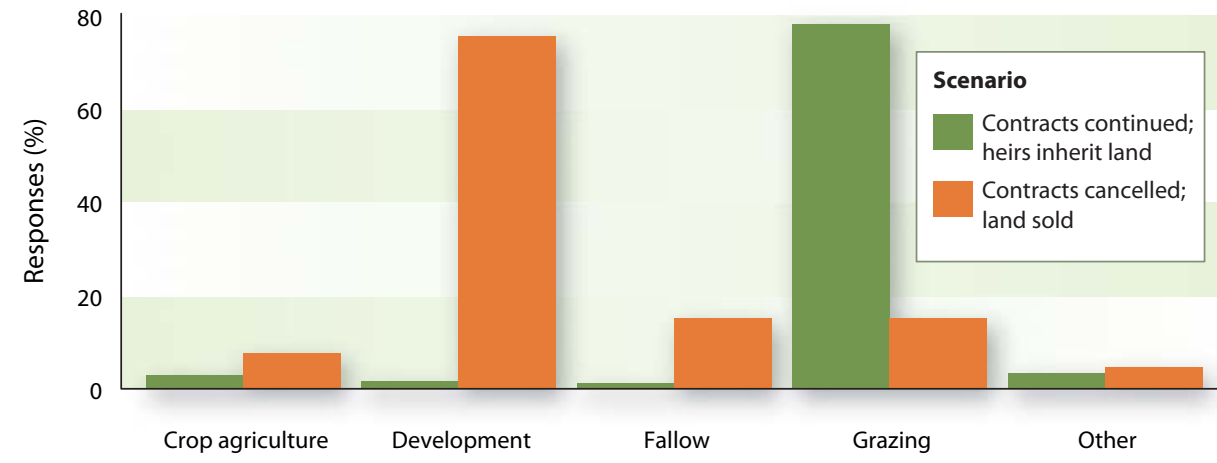

Fig. 4. Rancher predictions for future use of their land under ownership of heirs if Williamson Act contracts continued, and if they were eliminated and the land was sold.

results may exaggerate the absolute value of vulnerability, but only the relative value of vulnerability matters for these comparisons.

Household income and ranch profit. There was a strong negative relationship between household income and ranch vulnerability (fig. 3) but no relationship between ranch profit and vulnerability. Respondents with off-ranch employment or identifying as part-time ranchers tended to have higher household incomes. Ranchers with diversified ranch activities other than cattle production also intended to sell less land (23\% of total land owned) on average compared to ranchers whose sole ranch income came from cattle production (33\% of total land owned). In contrast, there was no relationship between ranch profit and vulnerability. The one exception to this trend was that none of the ranches earning over $\$ 100,000$ in profits intended to sell any land in the Williamson Act termination scenario.

Future land use. Predictions made by ranchers regarding the future use of their land showed a potential for loss of open space and rangeland in California if Williamson Act tax reductions ended. Ranchers predicted that $76 \%$ of the land sold in response to Act elimination would likely be developed commercially for nonagricultural, nonopen space uses including housing developments (fig. 4). Only $15 \%$ of these same ranchers listed continued grazing as a likely future land use after sale. In contrast, the majority of respondents $(78 \%)$ reported that their heirs would continue grazing their land if Williamson Act contracts continued. Fewer than $2 \%$ reported that heirs would develop their rangeland for urban or suburban use. While these numbers do not directly translate to an estimate of the total acreage that would be developed, they do suggest that land passed to heirs might have a greater chance of escaping development than land put up for sale in the event of Williamson Act elimination. Commercial development is only one of several possible outcomes for land sold by ranchers, but the fact that this was the most commonly predicted outcome is alarming.

Trends in ranch vulnerability. Household income played the strongest role in determining the probability that a rancher would intend to sell land, with higher income groups intending to sell less land 
than low-income ranchers. Interestingly, $5 \%$ of ranchers earning $\$ 100,000$ or more in annual household income reported that they did not know their ranching operational profit from 2009. This finding suggests that among wealthier owners, ranching profits play a small role in land sale decisions. The $5.6 \%$ of respondents who reported annual household incomes of less than $\$ 25,000$ and profits less than $\$ 10,000$ were the group with the greatest vulnerability. Diversification away from sole dependence on conventional ranching activities is an emergent trend in the economic landscape of California ranching (Rilla et al. 2011). Survey respondents who were part-time ranchers, had off-ranch employment or earned ranch income from sources other than cattle (e.g., agritourism) reported far lower ranch vulnerabilities. That ranch diversification decreases economic vulnerability should be an important lesson for ranchers and conservationists in California.

Development pressure. Most ranchers who intended to sell land in the Williamson Act elimination scenario indicated that they believed it would be developed for nonagricultural use. This trend suggests that many ranchers perceive significant development pressures in the areas surrounding their parcels. The location of rangeland parcels will determine the scale of property tax increases in the absence of the Williamson Act savings and obviously influence the degree of development pressure and the land's resale value. If development across California follows previous models for the Mojave Desert regions, land located close to cities and other development is more likely to develop first (Gomben et al. 2012) and thus may see a larger increase in property taxes without the Williamson Act. Land sale by economically vulnerable ranch households may be more likely in these areas.

Heirs. A major finding of our study was that a majority of ranchers believed their heirs would continue to commercially graze their properties when land is passed to them (fig. 4). This suggests that if the Williamson Act remains in place, ranching communities and rangeland in California may be protected in the near future, and that the Williamson Act is meeting its goal of preserving agricultural communities and ranching landscapes in California.

\section{Conservation value of nonprime parcels}

Out of 102,384

nonprime

Williamson Act parcels within the CRCC study region, 43,639 were located within CRCC "critical" habitat, and 29,672 were located within CRCC "important" habitat (fig. 5). Thus, $43 \%$ of nonprime Williamson Act parcels in our study area were classified as CRCC "critical," with an additional $29 \%$ classified as "important." A future without the Williamson Act in place may see increasing development and conversion of rangeland that is critical or important for conservation, putting ecologically valuable habitats at risk.

The large majority of nonprime Williamson Act parcels in our study area were located in the foothills encircling the Central Valley. CRCC habitats designated as either critical or important were scattered throughout the lower elevations of the foothills, with a patchy distribution spanning multiple habitat types generally dominated by oak savannas and grasslands (CRCC 2007b; LandFire 2010). These grassland habitats are home to native plants and animals and threatened vernal pool ecosystems and associated organisms, at least some of which benefit from moderate grazing (CRCC 2007b; Marty 2004).

\section{An important land management tool}

The Williamson Act has served as a land management tool for close to half a century by encouraging the conservation of agricultural lands, open spaces and rural communities throughout the state. Under the current state budget crisis, AB 1265 means that counties now must decide if they want to continue honoring Williamson Act contracts through the shortening of contract duration and the reduction of tax benefits to landowners. Many counties will likely continue with the modified version of the Williamson Act because the benefits are popular with property owners and the increase in revenue can compensate for the loss of state subvention payments. Some counties with major budget shortfalls, like Fresno,
Fig. 5. Conservation designation of all nonprime Williamson Act parcels within California Rangeland Conservation Coalition (CRCC) study area, showing high overlap between nonprime Williamson Act parcels and CRCC conservation habitat (CRCC 2007b).

have already gone down the road of reducing benefits to landowners. Beyond politics, a fundamental question is what will happen to rangeland and ranching in California if counties begin to eliminate Williamson Act contracts (fig. 6).

Results of this study show that ranchers perceive the Williamson Act to be a critical component of their ranching businesses. Ranching is a low-profit venture nationally (Gosnell and Travis 2005). Our study confirms this for California: $71 \%$ of Williamson Act-enrolled ranchers reported a net annual profit equal to or less than their Williamson Act property tax savings in 2009. Williamson Act tax reductions make the difference between profit and loss for the majority of California ranchers in the Central Valley and surrounding foothills. Ranchers with high annual household incomes, typically earned from off-ranch employment, seemed less likely to be influenced by a decrease in profits or changing property 


\section{Ranchers and the ranching industry}

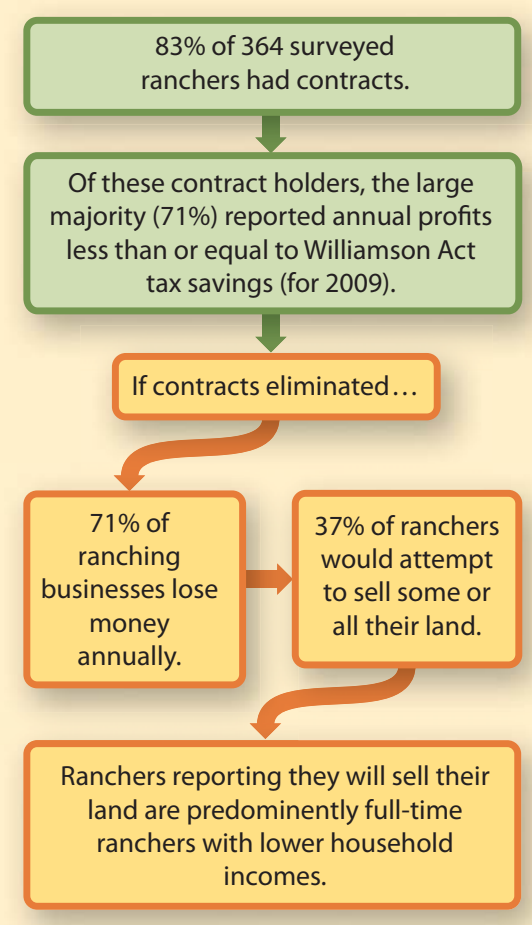

\section{Rangeland environment}

$72 \%$ of nonprime Williamson Act parcels are important or critical for conservation.

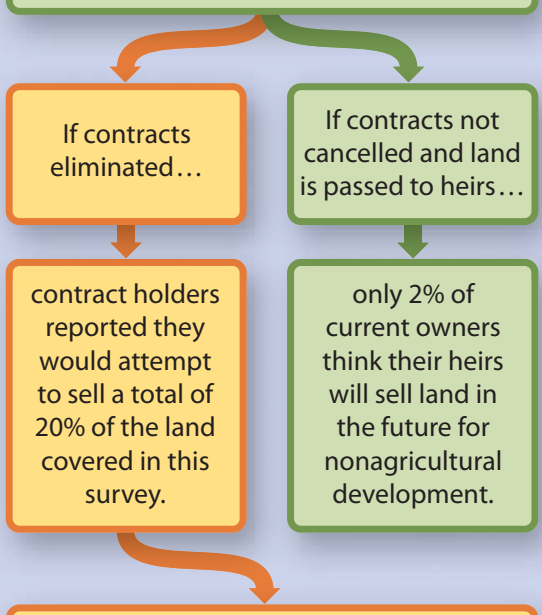

$76 \%$ of ranchers who reported they would sell land if their contracts were cancelled predicted the land would be developed, leading to substantial rangeland losses.

Fig. 6. Possible consequences of eliminating Williamson Act contracts and property tax savings for ranching landowners.

tax burden. On the other hand, full-time ranchers with low annual household incomes frequently reported that they intended to sell land if they had to pay full property taxes in the absence of the Williamson Act. Our results indicate that the Williamson Act program buffers lowincome, full-time ranchers from fiscal insolvency. The likelihood that ranchers who lose their Williamson Act contracts would attempt to sell land increases among our survey population as household income decreases.

Nonrenewal of Williamson Act contracts could make large areas of rangeland throughout the state vulnerable to sale, and ranchers indicated that these lands would likely be commercially developed.
These lands have important conservation value and host numerous rare and endangered plant and animal species (CRCC 2007b). New conservation grazing and sustainable rangeland management practices (Brunson and Huntsinger 2008) hold significant promise as tools for integrating ecological conservation with agricultural production and preserving the integrity and beauty of the California landscape. Careful consideration of how policymakers can protect rangeland and its diverse habitats is of utmost importance in the years to come.
W.C. Wetzel is Doctoral Candidate, Department of Evolution and Ecology, UC Davis; I.L. Lacher is Doctoral Candidate, Department of Environmental Science and Policy, UC Davis; D.S. Swezey is Doctoral Candidate, Department of Evolution and Ecology, UC Davis; S.E. Moffitt is Doctoral Candidate, UC Bodega Marine Laboratory, Bodega Bay; and D.T. Manning is Doctoral Candidate, Department of Agricultural and Resource Economics, UC Davis. (All authors contributed equally.)

We acknowledge and thank Ken Tate, Jay Stachowicz, Carole Hom and Mark Lubell for their help with the research and manuscript. We also thank the California Cattlemen's Association and California Rangeland Conservation Coalition for collaborating throughout the project. The authors were supported by NSF DGE \#0801430, Responding to Rapid Environmental Change (REACH) IGERT, awarded to UC Davis. The UC Davis Russell L. Rustici Rangeland Watershed Sciences Endowment Fund provided additional support.

\section{References}

Andersen MA, Blank SC, Lamendola T, Sexton RJ. 2002. California's cattle and beef industry at the crossroads. Calif Agr 56:152-6.

Barry S, Huntsinger L. 2002. Will California's working landscapes keep on working? Rangelands 24:6-10.

Bolker B. 2008. Ecological Models and Data in R. Princeton, NJ: Princeton Univ Pr. 408 p.

Brunson MW, Huntsinger L. 2008. Ranching as a conservation strategy: Can old ranchers save the new west? Rangeland Ecol Manage 61:137-47.

[CDF-FRAP] California Department of Forestry and Fire Protection Fire and Resource Protection Program. 2010. California's Forests and Rangelands: 2010 Assessment. http://frap.cdf.ca.gov/assessment2010/pdfs/california forest_assessment_nov22.pdf (accessed August 2011). [CRCC] California Rangeland Conservation Coalition. 2007a. Biological Prioritization of Rangeland: Approach and Methods. www.carangeland.org/images/Appraoch and_Methods.pdf (accessed August 2010).
CRCC. 2007b. Focus Area Prioritization: Map. www. carangeland.org/images/Rangeland_Coalition_Map.pdf (accessed August 2010).

Dillman DA. 2000. Mail and Internet Surveys: The Tailored Design Method (2nd ed.). New York, NY: J Wiley Sons.

$480 \mathrm{p}$.

Gomben P, Lilieholm R, Gonzalez-Guillen M. 2012. Impact of demographic trends on future development patterns and the loss of open space in the California Mohave Desert. Env Manage 49:305-24.

Gosnell H, Travis WR. 2005. Ranchland ownership dynamics in the Rocky Mountain West. Rangeland Ecol Manage 58:191-8

Huntsinger L, Hopkinson P. 1996. Sustaining rangeland landscapes: A social and ecological process. J Range Manage 49:167-73.

Knight RL, Gilgert WC, Marston E. 2002. Ranching West of the 100th Meridian: Culture, Ecology, and Economics. Washington, DC: Island Pr. 196 p.

Knight RL, Wallace GN, Riebsame WE. 1994. Ranching the view: Subdivisons vs. agriculture. Conserv Biol 9:459-61
LandFire. 2010. Spatial GIS data. US Department of the Interior and US Department of Agriculture, Forest Service. www.landfire.gov/vegetation.php (accessed August 2010).

List JA, Gallet CA. 2001. What experimental protocols influence disparities between actual and hypothetical stated values? Env Resource Econ 20: 241-54.

Marty JT. 2004. Effects of cattle grazing on diversity in ephemeral wetlands. Conserv Biol 19:1626-32. Rilla E, Hardesty S, Getz C, George H. 2011. California agritourism operations and their economic potential are growing. Calif Agr 65:57-65

Sokolow AD. 2010. Budget cuts threaten the Williamson Act, California's longstanding farmland protection program. Calif Agr 64:118-20.

Sokolow AD, Bennett M. 2004. Conserving Agricultural Land through Compensation: A Guide for California Landowners. Agricultural Issues Center, UC Davis. 83 p. 